\section{They also serve}

William H. Press

The Joy of Insight: Passions of a Physicist. By Victor Weisskopf. Basic Books: 1991. Pp.336. \$24.95.

VICTOR Weisskopf, is a fortunate and happy individual, and he does not mind telling us so. Born in Vienna in 1908 to a well-to-do and intensely cultured Jewish family, Weisskopf lived through the Nazi destruction of European culture and science without harm to himself or any of his immediate family. An emigré in Rochester, then a Manhattan Project group leader at Los Alamos, and later an active citizen in the United States on issues of arms control and nuclear disarmament, he returned to Europe to play a significant role in the re-emergence of large-scale European science at CERN in the 1960s. Subsequently he has been a much-honoured senior statesman of science, a fixture of the Cambridge, Massachusetts, and world scenes, a man who summers in his 'petit paradis', a chalet on the slope of the Jura Mountains with a view of Mont Blanc.

And what physicist would not trade 10,000 citations in the Science Citation Index for a chance to have been where Weisskopf was, so often at the very centre of the action of twentieth-century physics? As a student in gymnasium, he read voraciously the popular accounts of the then infant quantum mechanics, wrote a letter to Planck and received a postcard reply (a wrong explanation, we now know). Hans Thirring, his undergraduate mentor in Vienna, sent him on to Göttingen, where he studied under Max Born, James Franck, Paul Ehrenfest and Richard Courant, among others. For recreation there were trips to Berlin to see the musical theatre of Brecht and Weill and their followers, or a week in Jena listening to Furtwängler conducting Brahms.

In 1931, doctorate in hand, Weisskopf went to Leipzig, to work with Heisenberg (alongside Yoshio Nishina and Felix Bloch); Schrödinger invited him to Berlin as his assistant. "Often I saw the Nazi gangs . . . beat up Jewish students or those who looked Jewish . . . More than once I had to pull one of the boys under attack into my office so that he could escape through the back door." Weisskopf spent a year in Copenhagen with Niels Bohr (where he met his future wife, Ellen), then several years as Pauli's assistant in Zürich. Expelled by the Swiss Fremdenpolizei for alleged leftist connections (a bureaucratic fabrication, he says), Viki and

Ellen spent some months in Copenhagen and Vienna, and crossed the Atlantic in 1937.

After the war and Los Alamos, Weisskopf was recruited to the Massachusetts Institute of Technology, where he became a powerful department head, wrote a classic textbook on theoretical nuclear physics, and supervised graduate students and postdoctoral fellows including Sid Drell, Murray Gell-

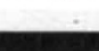

